\title{
Reflecting on Chemical Education: Nilratan Dhar and the Legacy of P C Ray
}

\author{
Madhumita Mazumdar*
}

(Received 7 May 2018; revised 4 June 2018)

\begin{abstract}
This paper takes a close look at the chemist Nilratan Dhar's memoirs published as Reflections on Chemical Education in 1974 and tries to understand how Dhar's renditions of his life and career bore the imprints of his teacher and mentor Acharya Prafulla Chandra Ray. It argues that Dhar drew upon Ray's historicizing impulse to tell us not only a story of his own life but also a larger history of chemical research under colonial conditions on the one hand and the Great Wars on the other.
\end{abstract}

Key words: History of physical chemistry, Industrial synthesis of Ammonia, Photochemical fixation of Nitrogen, The Great War.

\section{INTRODUCTION}

By all accounts Prof Nilratan Dhar (18921986) remains one of the most respected practitioners of modern Indian Chemistry. His professional attainments as scientist and teacher together with his philanthropic works are well recorded and known. What is equally well known is the affection he received from his teacher Acharya Prafulla Chandra Ray (1861-1944) and the deep intellectual and personal bonds he shared with him in the formative years of his career. ${ }^{1}$ Dhar was part of extraordinary group of young students in Presidency College and later Calcutta University whom Ray inspired with spirited teaching, intellectual comradeship and patriotism. Many in that group were to become pioneers in shaping an Indian School of Chemistry while others excelled in Physics. The names that are associated with this group are those of Meghnad Saha, Satyen Bose, Jnan Chandra Ghosh, Jnan Mukherjee and Nilratan Dhar himself (Mazumdar, 2010, pp.836-842).
The objective of this paper is not to reiterate or to describe in depth the intellectual content of Dhar's researches in Physical Chemistry or elaborate on the specifics of his greatest achievement on the photochemical fixation of Nitrogen, but to explore the legacies of Ray in Dhar's chronicling of his own life and work. I focus on this aspect of Ray's legacy in the works of Dhar, to suggest that apart from the formal training Ray imparted to his students, Ray instilled in them a sense of the significance of historical reflection on their practice. Ray's memoirs titled 'Life and Experiences of a Bengali Chemist' published in two volumes in the 1930s is testimony to the value he placed on delineating a genealogy of his discipline and the historical contexts within which it developed. While Ray was evidently inspired by the French chemist Berthelot in his interest in the historical development of Chemistry he may have also followed what has been described as a quintessentially late $19^{\text {th }}$ century practice among

\footnotetext{
* Dhirubhai Ambani Institute of Information Communication Technology, Gandhinagar-382007 Email: madhumita_mazumdar@daiict.ac.in

1 A recent study that testifies to this bond between P C Ray and Nilratan Dhar, see Choudhuri and Singh, 2018.
} 
chemists in Britain to integrate history of their discipline with the formal training of their students. As the historian Mary Joe Nye, observes, thinking about the problem of disciplinary identity as a variant of the constitution of national identity was particularly evident in the $19^{\text {th }}$ century when both nation building and discipline building were characteristic activities of industrial societies (Nye, 1993, p.19). In colonial India, Ray's two volumes of A History of Hindu Chemistry (1902 and 1909) were examples of this convergence of a nationalist impulse with that of a historicizing impulse.

Although Ray's legacies can and be addressed through the lives and achievements of scores of his students and through multiple sources, the specific purpose of this paper is to draw attention to the memoirs of one of his favourite students, Dr. Nilratan Dhar. It argues that Dhar's slim volume titled Reflections on Chemical Education published by the Indian Chemical Society in 1974 needs to be read more widely as a rich and valuable resource that gives us a rare insider's view into the shaping of chemical research in India within a complex web of intersecting historical intellectual and political contexts.

While disciplinary histories of chemistry have been written in recent times, the Indian story seldom finds place in western narratives. In the absence of a systematic archive of Dhar's private papers this published volume provides an important window into the shaping of his career under conditions of colonial rule as well as the larger interwar context of global science.

\section{Ray ANd the Historicizing Impulse}

Acharya Prafulla Ray's autobiography/ memoir often doubles up as a history of chemistry too, as Ray interspersed the narrative of his life with frequent reflections on lives of chemists, industrial and basic research, national academic traditions and great works. His life was irrevocably bound up not only with the destiny of Bengal or India but with the tentative directions of his discipline.

When the Indian School of Chemistry had come to be recognized as such Ray was generous to chronicle not only his own contributions to it but dwell at length upon the accomplishments of his students. In a longish chapter titled, 'Original Research, Research Scholars and the Indian School of Chemistry' he began with a brief description of the objective conditions of research in Bengal at the turn of the century, the availability of scholarships, laboratory facilities and the opportunities for a career in academics through the Provincial or Imperial Educational services. But soon after went onto describe his own contributions toward nurturing a young group of researchers into new areas of chemical research. Ray's chapter laid out what could be described as the objective conditions of research under colonial rule as well as the subjective or affective conditions that drew his students into it. Yet beyond these micro-histories of the classroom there was another dimension that Ray brought to bear in his account of the origins of the Indian School of Chemistry. This was the larger and more complex web of intellectual and political constraints within which scientific disciplines emerged, matured and consolidated (Ray, 1996, pp. 182-195).

Ray introduced his own rendition of the history of Physical Chemistry cautiously but persuasively. 'When I was a student at Edinburgh', he wrote,

Physical Chemistry was still in the making: its great protagonist Svante Arrehenius (1859-1927) was actually carrying out in Stockholm his experiments on the conductivity of solutions with respect to electric currents almost contemporaneously during my stay in Edinburgh. I well remember how the Swedish chemist, in those days was assailed by the conservative school for heterodox views; nay ridicule was heaped on him. In due course his bold 
theory received acceptance and even approbation from the scientific world. His scoffers turned out to be his best admirers (Ray, 1996, p.172).

Although Ray refused to name the 'conservative school' it was evident that he referred to Arrhenius's staunchest critics in the British chemical establishment and in the context of this controversy it was clear that Ray stood behind Arrhenius.

Later historians of Physical Chemistry have concurred wholly with Ray's account in their descriptions of the intense debate and acrimony that birthed the research schools of Physical Chemistry in Britain and Europe. The controversy raged between the European school of Svante Arrhenius (1859- 1927), Wilhelm Ostwald (18531932), and Jacobus van't Hoff (1852-1911) who believed that salts partially dissociated when dissolved in water, and the British school of Henry Armstrong (1848-1937), Spencer Pickering (18581920), and George Fitzgerald (1851-1901) who regarded the dissociation hypothesis as unthinkable and lacking in firm laboratory evidence (Dolby, 1976, pp. 297-98).

With his numerous examples from history of chemistry, Ray made his students aware that disciplinary knowledge developed through dissent, confrontation and dialogue and rarely through smooth accumulation of knowledge in a linear and logical sequence. He also drew attention to the fact that young students had often had to pass their ideas through the contentious routes of warring journals, conferences and cliques before they acquired legitimacy and broader acceptance.

By his own admission, Dhar's intellectual forays into physical chemistry were inspired by Ray in the classrooms and laboratory of Presidency College. Beginning with the identification of a research interest, to the performance of collaborative experiments and the publication of joint papers, Ray introduced Dhar to the wider world of chemical research. Drawing upon the key tracks of contemporary research Ray sought to introduce his students to a variety of experimental data that was used by the European school to promote the idea of the dissociation of salts in aqueous solution. Dhar was quickly drawn to these areas of interest and collaborated with Ray in experiments and international scientific publications from 1911 onwards (Ray, p.186).

\section{DhaR's ReFlections on CHEMICAL EDUCATION}

Dhar's Reflections on Chemical Education, 1974, takes Ray's early descriptions of the beginnings of Physical Chemistry in India and develops two parallel narrative tracks. One narrating the growth, maturation and diversification of his research interests and the other of his successful maneuvers within contending academic networks in Britain, France, Germany and Sweden. Significantly, his reflections on the first few years of his life as a doctoral student in Britain and later in France at the height of the Great War offer an immediate insight into the recurrent contingencies of his research career. Dhar's examples of these are many. For example, Dhar was keen to work with F G Donnan of the University College London, but immediately upon his arrival heard that the Physical Chemistry laboratory was in a state of renovation and repair and that there was no ready space or equipment for him to work with. He then requested J C Philip of the Imperial College if he could take him on but was told that the rules of the University candidates seeking admissions for DSc required the candidate to work independently of the Professor (Dhar, 1974, p. 15-16).

Undeterred by these initial disappointments, Dhar tells us that he began work on problems that he brought with him from Calcutta. He studied the mechanism of reaction between mercuric chloride and oxalic acid induced by potassium permanganate. He studied these reactions at various temperatures and remained 
focused on the continuation of researches in induced reaction. It was at this time and purely on his own initiative that he also began to study photochemical reactions between oxalic acid and mercuric chloride and also began extensive studies on chemical kinetics using all the literature available at the South Kensington Museum and Library (Dhar, 1974, p. 17).

Yet the study and work in Britain seemed incomplete as he wrote, 'I wanted to work in another lab' (Dhar, 1974, p.17). Letters were thus sent to Arrhenius at Stockholm in an attempt to find a research fellowship at the Nobel Institute. But the replies were deeply discouraging. There were food shortages in Sweden and German submarines in the North Sea, in other words it was a period of intense wartime crisis. In these circumstances it was not advisable for an Indian student to make way to Sweden to pursue doctoral work (Dhar, 1974, p.18).

The disappointment of not being able to go to Sweden was palpable in Dhar's rendition of the incident, yet he didn't let his spirit lag. Soon after the rejection from Sweden, Dhar decided on his next option, to work with Prof Paul Sabatier in Toulouse but there were wartime exigencies there too as the entire chemistry laboratory was burnt down and out of use. The final successful destination was Prof George Urbaine's laboratory at Sorbonne University in France. Prof Urbaine took on Dhar, and requested the French military authorities to influence the British Government to allow him passage to France. Dhar's advisor in Britain Prof J C Philips was disapproved of his decision and felt that France was deep in the clutches of War and not in a position to support research. He wasn't wrong. The conditions at Sorbonne were poor, there was no heating in the lab and no equipment to carry out the experiments Dhar had prepared to do. He limited himself to research on chemical kinetics and catalysis and wrote up his thesis and finally submitted in October 1918 (Dhar, 1974, p.20-1).
I have dwelt on Dhar's rendition of the early years of his research career to draw attention to the bearing this experience had on his subsequent research work and the early development of a distinctive outlook on the purposes of his discipline. He was particularly aware of the futility of War, the antagonisms between nations and the role of Chemistry in the destruction of human lives. These issues were discussed at various points in the subsequent chapter that dwelt on his work back in India as Professor of Chemistry at the Muir Central College in Allahabad, and more importantly during the descriptions of his next major visit to Europe in 1926 (Dhar, 1974, pp.33-48).

After seven years of service at the Muir College Dhar wrote that he was granted study leave in Europe for about six months from May 1926 (Dhar, 1974, p.49).

This brief paragraph describing his visit to Germany was followed by a series of significant observations on the Kaiser Wilhelm Institute for Physical Chemistry and Electrochemistry, the broad conventions of academic research outside the university system, the recognition of the Directors and Deputy Directors as University Professors, the ethos of collaboration between them and doctoral candidates and most importantly the institution of the colloquium. It is the colloquium that allowed Dhar to witness the open and almost egalitarian conventions of scientific debate, the practices of dissent and the importance of respecting difference of opinion. Within the Kaiser-Wilhelm Institute too Dhar observed that notwithstanding the commanding presence of Fritz Haber (1868-1934) there were many others who commanded equal respect and had the courage to disagree too (Dhar, 1974, pp. 50-51).

It is important to note here that although Haber remained a significant point of reference in Dhar's researches and he didn't hesitate to 
dissent with his methods even at the very early stages of his research on photochemical fixation of nitrogen.

Dhar's early criticism of Haber in this context is important. In his own words, Haber's aim was to get the maximum yield of ammonia at a very high temperature and pressure. Unfortunately in industry there was a conversion of about $8-10 \%$ of the gas mixture to ammonia and as the temperature and pressure had to be high and ammonia synthesis according to the HaberBosch method was costly. Yet Dhar knew that despite the costs, the German government supported the Haber-Bosch method because its real motives were different. It was to utilize this ammonia by oxidation to produce nitric acid for obtaining high explosives for war (Dhar, 1974, p. 51).

This early critique of Haber and the destructive association of chemistry with war would be reiterated in other contexts too. Yet Dhar seemed to be torn between his admiration for the intellectual attainments of Haber on the one hand and criticism of his compromise with the German state and its war efforts on the other. Fritz Haber, he wrote, was a

very versatile and extremely clever German chemist of international reputation. He loved Science and literally lived for it. He believed in the moral value of scientific research and its moulding influence on human life. He was of the opinion that Science held a key position in the domains of culture and civilization and that scientific research was needed for the preservation of mankind. He considered the pursuit of applied science and technical problems as almost honorable as the pursuit of pure science (Dhar, 1974, pp.7172).

It was evident that the involvement of the world's finest scientific minds bothered Dhar and it seemed to him that the task at hand was to remind scientists around the world that the mistakes of the French chemist Victor Grignard (1871-1935) and Haber should not be repeated and that the efforts of science and chemistry in particular had to be redirected towards problems of human food shortages rather that of war (Dhar, 1974, p.85). Although Haber's contributions to the enhancement of agricultural production were always celebrated, his involvement in chemical gas warfare seemed to undermine the fame and respectability he enjoyed. For Dhar the War had inadvertently shown the limits and dangers of science and urged the need to focus research interests henceforth to the solution of the larger and more pressing problems that were facing human kind (Dhar, 1974, p.86).

It was thus from the 1930s onwards that despite all the positive evaluation of Haber's commitment to science and its moral valence Dhar mounted a frontal attack on the industrial synthesis of ammonia. In a longer reflection on nitrogen fixation and nitrogen loss, Dhar took the categorical position that the high hopes of the Nobel Committee regarding the Haber synthesis of ammonia for improving agriculture and the welfare of mankind had not been realized. In fact in what was perhaps his most scathing indictment of Haber, Dhar wrote,

On considering this matter for nearly 55 years, it
appears to me that in certain respects Science has
failed in the proper development of human nature.
It is intolerable to think that two great men, who
were excellent human beings and on top the best
scientists and recipients of the Nobel Prize that is
Grignard and Haber, spent their long years in
devising horrible weapons to kill innocent men and
women of a neighboring country during the war
(Dhar, 1974, p.85).

It is instructive to note the confidence in Dhar's voice. His research on the photochemical fixation of nitrogen had been successfully demonstrated at the Royal College of Agriculture at Uppsala, and his arguments in favour of a Chemistry to solve the world's food problem was much appreciated. The theme of 'Science for Peace' and for the regeneration of human life rather than its mindless destruction was a perhaps 
a fitting denouement to his Reflections on Chemical Education, which began with an account of the contingent trajectory of his researches in the midst of the Great War to the crowning moments of his success and recognition achieved in the immediate aftermath of the convulsions of the Holocaust and the second World War.

\section{Concluding Remarks}

Dhar was in some ways a quintessentially interwar scientist. The appellation assumes significance when we focus on the complex intellectual, political and ethical choices that the two World Wars presented scientists of his generation. He was a colonial scientist too, which brought with it a different sort of historical conditions that informed his research interests. It is these dilemmas, challenges, opportunities and constraints that come across in his reflections and offers us new ways of understanding and appraising his contributions to physical chemistry and the Indian research tradition within it.

Yet the real significance of his memoir perhaps lies the many implicit conversations it had with Ray his intellectual mentor, and Ray as a chronicler of the history of chemistry. Dhar much like Ray strove to weave in the narrative of his own self-formation as a chemist within a larger narrative of discipline formation. His Reflections stand out as a tribute to the legacy of Ray as both chemist and chronicler and as one who believed that historical reflection was integral to scientific practice, its ethical implications and to nation building at large.

\section{BibLIOGRAPHY}

Choudhuri, Arnab Rai and Singh, Rajinder. The FRS nomination of Sir P C Ray and the correspondence of N R Dhar', Notes and Records: the Royal Society Journal of the History of the Science, 72 (2018): 5773.

Dhar, N R. Reflections on Chemical Education, Indian Chemical Society, Calcutta, 1974.

Dolby, R G A. Debates over the Theory of Solution: A Study of Dissent in Physical Chemistry in the EnglishSpeaking World in the Late Nineteenth and Early Twentieth Century, in Historical Studies in the Physical Sciences, Vol. 7, University of California Press, California, 1976, pp. 297-404.

Mazumdar, Madhumita. P C Ray and the Making of an Indian School of Chemistry, Calcutta 1889-1924 in Uma Dasgupta and D P Chattopadhyay (eds) History of Science, Philosophy and Culture in Indian Civilization Vol.XV, Part Four, Science and Modern India 1784- 1947, Pearson Education India, New Delhi, 2010.

Nye, Mary Jo. From Chemical Philosophy to Theoretical Chemistry: Dynamics of Matter and Dynamics of Disciplines, 1800-1950, University of California Press, Berkeley/Los Angeles/London, 1993.

Ray, Prafulla Chandra. Life and Experiences of a Bengali Chemist, Volume One, The Asiatic Society Edition, Calcutta, 1996, First published, 1932. 